\title{
Resveratrol Nanoemulsion; A Promising regulator of TGFB1and TFF-3 Genes Expression in DSS-Induced Ulcerative Colitis in Rats
}

\section{Riham A Mahmoud ${ }^{1}$, Mohamed S Naser Eldin' ${ }^{1}$, Ali A Ali ${ }^{2}$ and Mohammed A Hussein ${ }^{3 *}$}

${ }^{1}$ Radiology Department, Faculty of Applied Medical Sciences, October 6 University, Sixth of October City, Egypt

${ }^{2}$ Vice president of post graduate studies, October 6 University, Sixth of October City, Egypt

${ }^{3}$ Biochemistry Department, Faculty of Applied Medical Sciences, October 6 University, Sixth of October City, Egypt

*Corresponding Author: Mohammed A Hussein, Biochemistry Department, Faculty of Applied Medical Sciences, October 6 University, Sixth of October City, Egypt.

DOI: 10.31080/ASNH.2020.05.0808
Received: October 22, 2020

Published: January 16, 2021

(C) All rights are reserved by Mohammed A Hussein., et al.

\begin{abstract}
Background: Immunosuppressants or anti-inflammatory drugs was used in treatment of bowel disease. The aim of the present article was to evaluate the intestinal anti-inflammatory properties activity of resveratrol nanoemulsion (RENE) against ulcerative colitis induced by DSS in rats.

Results: RENE was prepared with size of $49.5 \pm 0.05 \mathrm{~nm}$ and zeta potential of +15.75 with the observed shapes of nanoparticle was spherical. Also, RENE (39.75 mg/kg b.w.) was administered orally to DSS-induced colitic rats for 21 days.

RENE $(100 \mu \mathrm{M})$ significantly reduces in vitro the release of TGFB1 in the extracellular matrix of in human intestinal colorectal adenocarcinoma cell line and human colon carcinoma cell line HT29. The daily oral administration of the RENE at a concentration of $39.75 \mathrm{mg} / \mathrm{kg}$ body weight for 21 days to rats ameliorated the histological damage, body weight, DAI score, colon length and severity of DSS- induced colitis, and improved the compromised oxidative status of the colon. However, only the rats treated with RENE showed a significant reduction in the levels of different pro-inflammatory cytokines (TNF- $\alpha$ and MPO) and nitric oxide in comparison with the DSS control group. Moreover, RENE significantly decreases the gene expression of TGFB1 and IL-4 as well as significantly increases the gene expression of trefoil factor 3 (TFF3) in comparison with the DSS control group.

Conclusion: The results clearly suggest that RENE displayed intestinal anti-inflammatory properties in the DSS model of colitis in rats, which were improved by functionalization with the TGFB1, IL-4 and TFF3 gene expression.

Keywords: Resveratrol Nanoemulsion; DSS; Ulcerative Colitis; Colon Carcinoma; Nanoparticles Oxidative Stress Biomarkers and TFF3
\end{abstract}

\section{Abbreviations}

DSS: Dextran Sulfate Sodium; DAI: Disease Activity Index; IL4: Interleukin-4; MPO: Myeloperoxidase; NO: Nitric Oxide; RENE: Resveratrol Nanoemulsion; TGFB1: Transforming Growth Factor Beta 1; TNF- $\alpha$ : Tumor Necrosis Factor Alpha.

\section{Introduction}

Crohn's disease (Crohn's) and Ulcerative Colitis (UC) are the two major types of chronic idiopathic Inflammatory Bowel Disease (IBD) and have a wide ranging and often devastating impact on health and quality of life $[1,2]$. It is a disease of the young and 
for many inflicts a lifetime of relapsing and remitting activity $[3,4]$. There are some less common variants of UC, for example those patients who also suffer from UC associated Primary Sclerosing Cholangitis (PSC), and/or other extra intestinal manifestations in which IBD may be part of a syndrome rather than a distinct disease in itself [5].

MicroRNAs are essential for the normal function of inflammatory cells and immune homeostasis. Interruption of miRNA biogenesis, using either Drosha or Dicer knockout mice promotes Inflammation of the colon, decreased regulatory $\mathrm{T}$ cell function and rapidly fatal autoimmunity $[6,7]$. In the innate immune system, many microRNAs are expressed by macrophages in response to stimulation by cytokines [8].

In addition, proinflmmatory cytokines serve an important role in UC and have been associated with the severity of inflammation in colitis [9]. nuclear factor ( $\mathrm{nF})-\kappa \mathrm{B}$ p65 and is an important transcription factor that regulates of inflammatory genes including TNF $\alpha$, il-1 $\beta$, IL-6, IL-10, IL-12, and cyclooxygenase-2 [10,11]. Also, nF$\kappa \mathrm{B}$ increases B-cell lymphoma 2 (Bcl-2) expression, resulting in a decrease in cellular apoptosis [12-14].

Transforming growth factor- $\beta$ (TGFB1) has a critical role in cellular responses, such as development, proliferation and differentiation. TGF- $\beta$ is the master regulator to drive fibrosis in all organs including the intestine [15-17]. Canonical TGF- $\beta$ signaling via Smads has a central role in the progression of fibrosis [18].

Dextran sodium sulfate (DSS) colitis model is very popular in IBD research due to its rapidity, simplicity, reproducibility and controllability [19].

Resveratrol; trans-3,4',5-trihydroxystilbene; found in many species of plants, for examples; grapes, blueberries, peanuts [20] and red wine [21]. It has antioxidant and free radical scavenging properties [22] as well as anticholestatic activity [23] and effective in controlling of hyperglycemia and dyslipidemia in diabetes [24].

Nanotechnology allows scientists to target cancer cells [25]. Nanoparticles can decrease side effects in patients by directly targeting the area of disease and eliminating the need to circulate through the body $[26,27]$. When encapsulating drugs into nanoparticles, researchers observed improved drug solubility, controlled drug release, enhanced bioavailability, increased stability, and im- proved long-term storage (versus non-encapsulated drugs) [28]. These attributes are promising and could be the traits needed to combat disease [29-31]. In vivo tests have been conducted with resveratrol to determine for example, its anti-inflammatory in bowel disease [32,33]. But there are no reports of the effect of resveratrol nanoparticles in treatment of in bowel disease. As an extension of our interested research program to evaluate the medicinal importance of resveratrol $[22,26,34]$ we report herein, a facile route to evaluate the therapeutic potential of resveratrol nanoemulsion on DSS-induced ulcerative colitis in rat model. Therefore, in the present study we sought to understand whether the inhibition of TGFB1 through resveratrol nanoemulsion, is a good strategy to reduce intestinal inflammation. We show that resveratrol nanoemulsion, impairs TGFB1 activity and its administration causes a decreased loss of body weight and large intestine length as well as an amelioration in clinical and histological scores in mice with DSS-induced colitis.

\section{Methods}

Materials

Resveratrol (97\%.5\%), LPS, Trypan Blue, Bovine serum albumin and Glutaraldehyde 50\% were purchased from Sigma Chemical Co. (St. Louis, MO, USA). Dextran Sulphate Sodium (DSS, 98\%) was purchased from MP Biomedicals, UK. All other chemicals used in this study were of the analytical grade, preserved under standard situation, and were provided from standard commercial suppliers. Tween 80 was produced by Panreac Quimica, SA (Barcelona, Spain).

\section{Resveratrol nano-emulsion preparation}

Resveratrol nano-emulsion was prepared according the method of Hussein., et al. [34]. $100 \mathrm{mg}$ bovine serum albumin (BSA) is dissolved in $12 \mathrm{ml}$ distilled water; dissolve the resveratrol $24 \mathrm{mg}$ in 24 ml ethanol then add drop wise the ethanolic solution on the BSA solution under stirring (500 rpm); then add $3 \mathrm{ml} 11 \%$ glutaraldehyde and leave on stirring overnight.

\section{Resveratrol nano-emulsion characterization}

The crystalline nature and grain size of resveratrol nanoemulsion (RENE) was carried out by X-ray diffraction (XRD) pattern at 25-28 ${ }^{\circ} \mathrm{C}$ with a D8 Advance X -ray diffractometer (Bruker - Germany) with a nickel ( $\mathrm{Ni}$ ) filtered using $\mathrm{CuK} \alpha(\lambda=1.54184 \mathrm{~A} 0)$ radiations as an X-ray source. Infrared spectrum (IR) of sample is reg- 
istered using Nicolet 6700 (Thermo scientific-USA). The thermal analysis was measured using Thermo gravimetric analysis (TGA) TGA -50 (Shimadzu, Japan) Morphology and size of RENE were examined by Scanning Electron Microscope (SEM, JSM- 690, JEOL, Inc., Tokyo, Japan) and Field Emission Transmission Electron Microscopy (FETEM, JSM- 2100F, JEOL Inc.) at an accelerating voltage of $15 \mathrm{Kv}$ and $200 \mathrm{Kv}$.

\section{Cell culture}

The human intestinal colorectal adenocarcinoma cell line and human colon carcinoma cell line HT29 were cultured in Dulbecco's modified Eagle and McCoy's 5A media, respectively. All culture media contained $10 \%$ fetal calf serum (FCS), 2 mM L-glutamine, $100 \mathrm{U} / \mathrm{ml}$ penicillin and $100 \mathrm{mg} / \mathrm{ml}$ streptomycin (Biochrom, Berlin, Germany) at $37{ }^{\circ} \mathrm{C}, 5 \% \mathrm{CO}_{2}$. All cell lines were purchased from ATCC (Rockville, MD, USA). Cells were seeded with a cell number of $0.6 \times 10^{5}$ per well in six multiwell plates. Inductions were performed by adding to culture medium $1 \mathrm{mg} / \mathrm{ml}$ lipopolysaccharide (LPS), in presence or absence of resveratrol nanoemulsion (RENE) $(100 \mu \mathrm{M})$ dissolved in PBS. Total RNA and proteins were extracted for real-time PCR (RT-PCR) and western blot analyses. Supernatants were collected after $24 \mathrm{~h}$, briefly centrifuged, and extracellular TGFB1 by western blot.

\section{Animals}

Male albino rats weighing around $150 \pm 10 \mathrm{~g}$ was obtained from animal house of Faculty of Veterinary Medicine, Cairo University, Giza, Egypt. They were housed in plastic cages with stainless steel covers at the National Cancer Institute Animal House. The animals were maintained at a temperature of $22 \pm 1^{\circ} \mathrm{C}$ and a humidity of $55-60 \%$ in a light-controlled room. The animals were kept for 1 week to acclimatize and provided with standard diet and water $a d$ libitum.

\section{Experimental setup}

This experiment was carried out to examine the protective effect of RENE against DSS-induced ulcerative colitis. This experiment was conducted in accordance with guidelines established by the Animal Care and Use Committee of Adult female albino rats weighing around $150 \pm 10 \mathrm{~g}$ was divided into five groups with six animals in each. The treatment groups are described in table 1.

\section{Determining of disease activity index (DAI)}

The degree of disease activity index (DAI) in experimental colitis was measured in 3 ways; the first is by determining the weight

\begin{tabular}{|c|c|c|}
\hline Group & Group name & Treatment description \\
\hline I & $\begin{array}{c}\text { Normal } \\
\text { control A }\end{array}$ & $3 \mathrm{~mL}$ of distilled water, orally for 30 days \\
\hline II & $\begin{array}{c}\text { DSS positive } \\
\text { control }\end{array}$ & $\begin{array}{c}2.5 \%(\mathrm{w} / \mathrm{v}) \text { in drinking water (from day 15 } \\
\text { to day 21), orally for 7 days }\end{array}$ \\
\hline III & $\begin{array}{c}\text { Normal } \\
\text { control B }\end{array}$ & $\begin{array}{c}1 \mathrm{~mL} \text { of tween } 80,1 \% \text { distilled water, } \\
\text { orally for 30 days }\end{array}$ \\
\hline IV & RENE & $\begin{array}{c}\text { Oral suspension of 39.75 mg/kg b.w. in } \\
\text { tween } 80,1 \% \text { [34] }\end{array}$ \\
\hline V & RENE + DSS & $\begin{array}{c}\text { Oral suspension of 39.75 mg/kg b.w. RENE } \\
\text { in tween 80, 1\%, [34] 21 days before DSS. } \\
\text { 2.5\% (w/v) DSS in in drinking water (from } \\
\text { day 15 to day 21), orally for 7 days }\end{array}$ \\
\hline
\end{tabular}

Table 1: Description of treatment groups.

change of each rats weekly throughout this experiment. The second is by measuring the weight and length of the distal of resected colon. The third is by examining the clinical score (CS) of stool consistency according to the criteria of Maxwell., et al. [35] (0 for normal stool, 1 for moist/sticky stool, 2 for soft stool, 3 for diarrhea), presence of blood in stool ( 0 for no blood, 1 for evidence of blood in stool or around anus, and 2 for severe bleeding) and general appearance of the animal ( 0 was assigned if normal, 1 for ruffled fur or altered gait, 2 for lethargic or moribund). Rats were weekly weighed, and the percentage of weight loss was calculated in relation to the starting weight using the formula: [(Weight on day X- Initial weight)/ Initial weight] x 100 [35].

The $21^{\text {th }}$ day, at the end of the study, all rats were sacrificed, colons were excised, washed with phosphate buffer-saline (PBS), and dried between two filter papers. Colons were gently stretched and the distance from the colocecal junction to the end of the distal rectum was recorded [36]. Then distal portions of the colons were divided; one part was used for histopathological studies [35] and the other part were kept frozen at $-80{ }^{\circ} \mathrm{C}$ till biochemical analysis of thiobarbituric acid reactive substances (TBARS) [37], reduced glutathione (GSH) [38], superoxide dismutase (SOD) [39], catalase (CAT) [40], tumor necrosis factor alpha (TNF- $\alpha$ ) [41], nitric oxide (NO) [42], cyclic adenosine monophosphate (cAMP) [43], myeloperoxidase (MPO) [44] and total protein [45] content as well as quantitative real-time (qRT-PCR) for transforming growth factor beta 1 (TGFB1), trefoil factor 3 (TFF3), interleukin-4 ( IL-4) gene expression.

\section{Real-time PCR}

Total RNA of colon tissues and cell lines were extracted using RNA-spin ${ }^{\mathrm{TM}}$ total RNA extraction kit of (QiaGen GmbH, Hilden, Ger- 
many). $1-5 \mu \mathrm{g}$ total RNA was used for preparing cDNA by reverse transcription kit (Applied Biosystems, Foster City, CA). cDNA was used for qPCR using SYBR Green PCR master mix (iNtRON Biotechnology, Korea) as described by the manufacturer. Table 2 explain the sequences of primers (PrimerDesign Ltd, USA) used in RT-PCR were as follows.

\begin{tabular}{|c|c|c|}
\hline Gene & \multicolumn{2}{|c|}{ Sequence } \\
\hline \multirow{2}{*}{ TGFB1 } & forward & 5'-ACCTTCCGGGCAGCCTGTGA-'3 \\
\cline { 2 - 3 } & reverse & 5'-CAAGGAGGGTGGTGCGGCTG-'3 \\
\hline \multirow{2}{*}{ TFF3 } & forward & 5'-TAATGCTGTTGGTGGTCCTG -'3 \\
\cline { 2 - 3 } & reverse & 5' -CAGCCACGGTTGTTACACTG-'3 \\
\hline \multirow{2}{*}{ IL-4 } & forward & 5'-AACGAGGTCACAGGAGAAGG-'3 \\
\cline { 2 - 3 } & reverse & 5'-CACCTTGGAAGCCCTACAGA-'3 \\
\hline \multirow{2}{*}{ 3-actin } & forward & 5'-TGACTGACTACCTCATGAA- \\
(housekeeping) & GATCC-'3 \\
\cline { 2 - 3 } & reverse & 5'-TCTCCTTAATGTCACGCACGATT-'3 \\
\hline
\end{tabular}

Table 2: The sequences of primers used in RT-PCR.

For in vitro experiments the expression level of each mRNA was assessed using the standard curve method and GAPDH and $\beta$-actin were used for normalization.

For in vivo experiments, the expression level of each mRNA was assessed using the comparative $\mathrm{CT}\left({ }^{\Delta} \mathrm{C}_{\mathrm{T}}\right)$ method as described by the manufacturer.

\section{Statistical analysis}

The results were expressed as mean \pm SD for eight separate determinations. All the data were statistically evaluated with SPSS/18 Software. Hypothesis testing methods included one-way analysis of variance, followed by least significant difference test. $P$ values of $<0.05$ were considered to indicate statistical significance.

\section{Results}

IR spectrum infrared spectrogram of the basic resveratrol and resveratrol nanoemulsion shows a phenol hydroxyl groups absorption peak at 3252 and $3436 \mathrm{~cm}^{-1}$, respectively, as well as benzene ring absorption peaks at 2827, 2920 exists.

Light scattering techniques as well as transmission electron microscopy analysis shows that resveratrol nanoemulsion had size of around $49.5 \pm 0.05 \mathrm{~nm}$ with negative zeta potential of +15.75 .

Figure 1 show the in vitro effects of LPS $(1 \mathrm{mg} / \mathrm{ml})$ on gene expression and extracellular level of TGFB1 in human intestinal colorectal adenocarcinoma and human colon carcinoma cell lines in presence or absence of RENE $(100 \mu \mathrm{M})$. The obtained results revealed a significant elevation in plasma lipid profile levels. Nico-

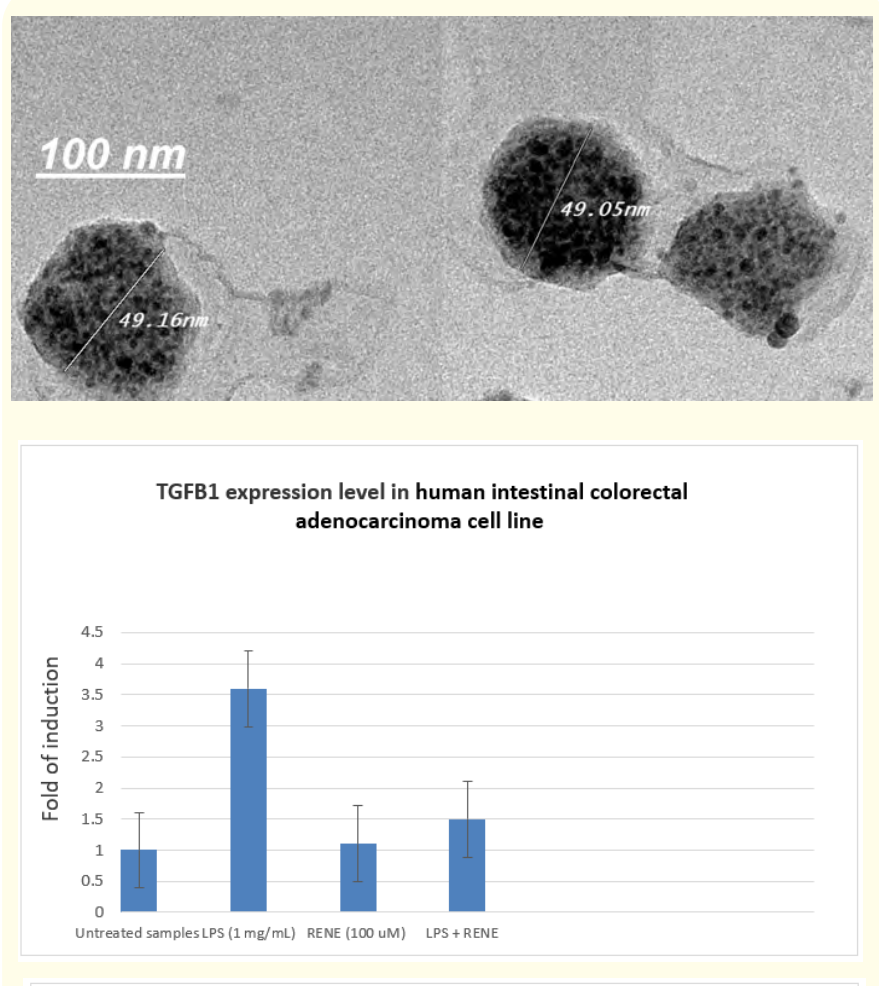

TGFB1 expression level in human colon carcinoma cell line HT29

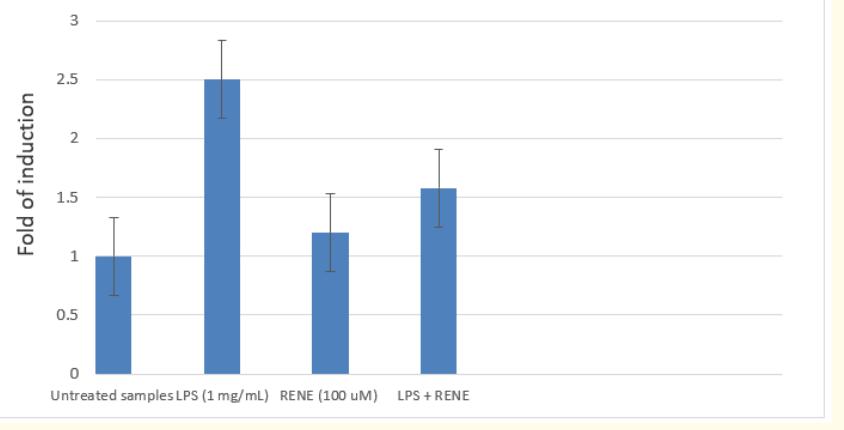

Figure 1: In vitro effects of RENE on gene expression and extracellular level of TGFB1 in human intestinal colorectal adenocarcinoma cell line and human colon carcinoma cell line HT29. The human intestinal colorectal adenocarcinoma cell line and human colon carcinoma cell line HT29 cell line was treated for 24 hours with LPS and RENE. Extracellular TGFB1 was then analysed in the culture medium by western blot. Data represent the target gene expression normalized to the reference gene. Values are the mean \pm SD of three independent experiments, referred to the optical density values of untreated samples.

tine (2.5 mg/kg.b.w.) administration for 30 days led to significant increase of TGFB1 gene expression in human intestinal colorectal adenocarcinoma and human colon carcinoma cell lines after exposer to LPS as compared with the normal control cell lines $(\mathrm{P}<$ 
0.05). Treatment of cell lines with RENE, significantly reduced the level of TGFB1 gene expression $(\mathrm{P}<0.05)$, as compared with the LPS treated cell lines.

Table 3 reveal a significant dramatic depletion in body weight of rats treated with DSS $(2.5 \%)$ as compared with control group during the $3^{\text {rd }}$ week $(\mathrm{p}<0.05)$. The administration of RENE $(39.75 \mathrm{mg} / \mathrm{kg} . \mathrm{b} . \mathrm{w})$ tended to restore the normal rate of weight gain relative to DSS treated group of rats after 21 days $(\mathrm{p}<0.05)$.

\begin{tabular}{|c|c|c|c|c|c|}
\hline \multirow{2}{*}{ No. } & \multirow{2}{*}{ Groups } & \multicolumn{4}{|c|}{$\begin{array}{c}\text { Number of weeks } \\
\text { Body weight of rats (g) }\end{array}$} \\
\hline & & 0 & 1 & 2 & 3 \\
\hline (I) & $\begin{array}{c}\text { Normal control A } \\
\text { (3 mL distilled water) }\end{array}$ & $\begin{aligned} & 183.6 \\
\pm & 11.0^{\mathrm{abA}}\end{aligned}$ & $\begin{array}{r}186.8 \\
\pm 14.6^{\mathrm{aA}}\end{array}$ & $\begin{array}{l}192.5 \\
\pm 8.7^{\mathrm{aA}}\end{array}$ & $\begin{array}{r}196.4 \\
\pm 10.5^{\mathrm{aB}}\end{array}$ \\
\hline (II) & $\begin{array}{l}\text { DSS positive control } \\
2.5 \%(\mathrm{w} / \mathrm{v}) \text { in drinking } \\
\text { water }\end{array}$ & $\begin{array}{r}179.5 \\
\pm 13.5^{\mathrm{aA}}\end{array}$ & $\begin{aligned} & 182.8 \\
\pm & 12.6^{\mathrm{aAB}}\end{aligned}$ & $\begin{array}{r}185.4 \\
\pm 11.8^{\mathrm{aB}}\end{array}$ & $\begin{array}{l}154.4 \\
\pm 8.5^{\mathrm{cC}}\end{array}$ \\
\hline (III) & $\begin{array}{l}\text { Normal control B } \\
\text { (1 mL of tween } 80,1 \% \\
\text { distilled water) }\end{array}$ & $\begin{aligned} & 180.5 \\
\pm & 10.6^{\mathrm{abA}}\end{aligned}$ & $\begin{aligned} & 185.8 \\
\pm & 14.2^{\mathrm{aA}}\end{aligned}$ & $\begin{array}{l}189.60 \\
\pm 11.3^{\mathrm{aB}}\end{array}$ & $\begin{array}{l}198.80 \\
\pm 15.6^{\mathrm{aC}}\end{array}$ \\
\hline (IV) & $\begin{array}{c}\text { RENE } \\
\text { (39.75 mg/kg b.w.) }\end{array}$ & $\begin{aligned} & 187.7 \\
\pm & 9.6^{\mathrm{abA}}\end{aligned}$ & $\begin{array}{r}194.6 \\
\pm 11.3^{\mathrm{bB}}\end{array}$ & $\begin{array}{r}198.7 \\
\pm 15.3^{\mathrm{cB}}\end{array}$ & $\begin{array}{r}204.7 \\
\pm 12.1^{\mathrm{bC}}\end{array}$ \\
\hline (V) & $\begin{array}{c}\text { RENE (39.75 mg/kg b.w.) } \\
+ \text { DSS }(2.5 \%(\mathrm{w} / \mathrm{v}) \text { in } \\
\text { drinking water) }\end{array}$ & $\begin{array}{l}184.70 \\
\pm 13.3^{\mathrm{aA}}\end{array}$ & $\begin{array}{l}189.85 \\
\pm 13.4^{\mathrm{aA}}\end{array}$ & $\begin{array}{r}197.8 \\
\pm 14.0^{\mathrm{bB}}\end{array}$ & $\begin{array}{r}188.4 \\
\pm 12.1^{\mathrm{aA}}\end{array}$ \\
\hline
\end{tabular}

Table 3: Effect of the RENE (39.75 mg/kg b.w.) on the weekly body weight of DSS treated rats.

Body weight of rats during the 3 -week period. Data shown are mean \pm standard deviation of number of observations within each treatment. Data followed by the same letter are not significantly different at $\mathrm{P} \leq$ 0.05. Small letters are used for comparison between the means within the column. Capital letters are used to compare means within the row.

Figure 2 show a significant increase in the DAI score after DSS treatment compared to those of the control group. However, treatment with RENE (39.75 mg/kg.b.w) significantly decreased the DSS-induced DAI score compared to those of the DSS group $(\mathrm{p}<0.05)$.

Figure 3 show a significant decrease in the colon length of rats after DSS treatment compared to those of the control group. However, treatment with RENE (39.75 mg/kg.b.w) tended to restore the normal rate of colon length gain as compared to those of the DSS group ( $p<0.05)$.

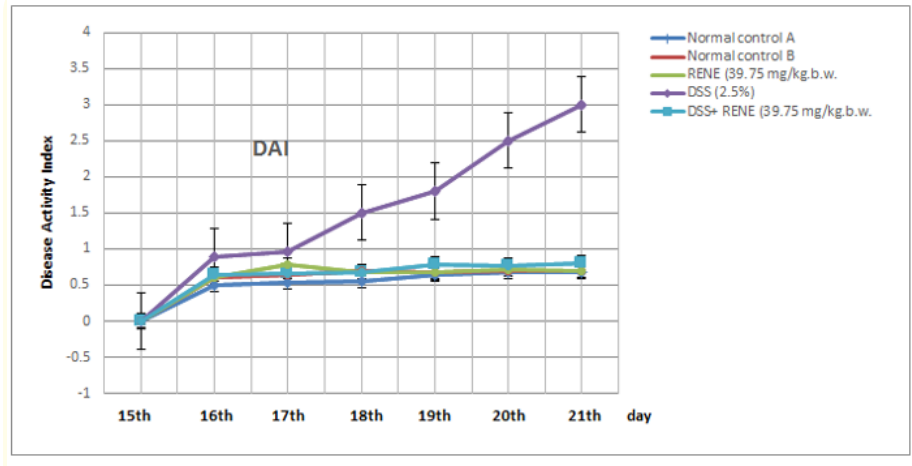

Figure 2: Effect of RENE (39.75 mg/kg b.w.) on disease activity index in DSS induced colitis groups of rats for 7 days (from day 15 to day 21), orally for 7 days). Data was expressed as mean \pm SEM $(n=$ 6 ). The obtained values were significantly different at $\mathrm{P} \leq 0.05$.
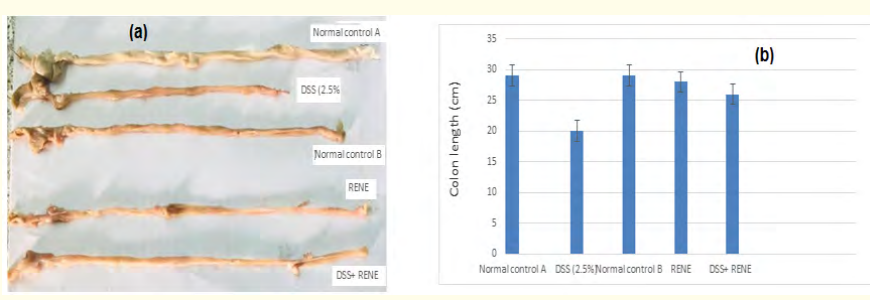

Figure 3a and 3b: Effect of RENE (39.75 mg/kg b.w.) on colon length in DSS induced colitis groups of rats. Data was expressed as mean \pm SEM $(n=6)$.

Figure 4 show the length of the colon is inversely linked to the severity of DSS-induced colitis. The treatment of DSS caused a reduction in colon length and significant increase in the relative colonic weight/ length ratio in both acute and chronic groups compared to control animals ( $\mathrm{p}$ < 0.05). treatment with RENE (39.75 mg/kg.b.w) markedly reduced macroscopic damage in DSS induced animals and decreased the colon weight/length ratio as compared to those of the DSS group $(\mathrm{p}<0.05)$.

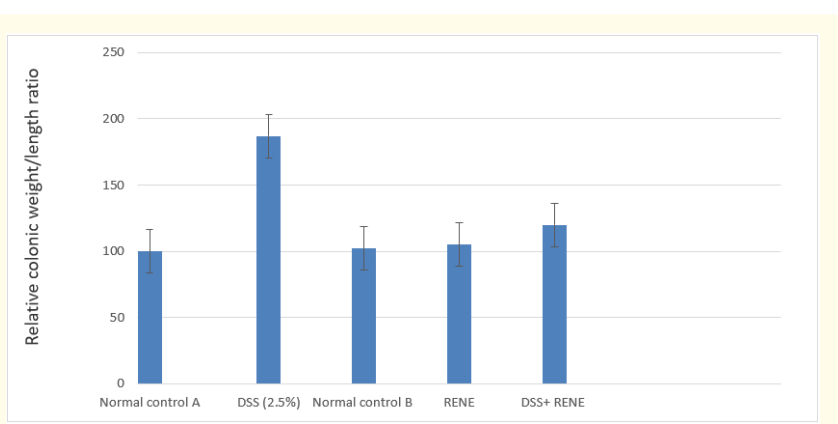

Figure 4: Effect of RENE (39.75 mg/kg b.w.) on relative colonic weight/ length ratio in DSS induced colitis groups of rats. Data was expressed as mean \pm SEM $(n=6)$. The obtained values were significantly different at $\mathrm{P} \leq 0.05$. 
23

Tables 4 and 5 show a significantly $(\mathrm{P}<0.05)$ decreased colon levels of reduced glutathione (GSH) superoxide dismutase (SOD), catalase (CAT) and cyclic adenosine monophosphate (cAMP) while significantly increasing colon thiobarbituric acid reactive substances (TBARS), tumor necrosis factor alpha (TNF- $\alpha$ ), nitric oxide (NO) and myeloperoxidase (MPO) in the DSS-treated rats as compared with the normal control group $(\mathrm{P}<0.05)$, indicating acute colon damage. RENE $(39.75 \mathrm{mg} /$ kg.b.w) significantly $(\mathrm{P}<0.05)$ enhanced the colon enzymes activities SOD, CAT and cAMP as well as level of GSH in rats and decrease TBARS, TNF- $\alpha$, NO and MPO levels, as compared to the DSS-treated group.

\begin{tabular}{|c|c|c|c|c|c|}
\hline No. & Groups & $\begin{array}{c}\text { TBARS } \\
\text { (nmol/ mg } \\
\text { protein) }\end{array}$ & \begin{tabular}{|c|} 
GSH \\
mg/100 \\
g tissue
\end{tabular} & $\begin{array}{c}\text { SOD } \\
\text { (U/mg } \\
\text { protien) }\end{array}$ & $\begin{array}{c}\text { CAT } \\
\text { (U/mg } \\
\text { protien) }\end{array}$ \\
\hline (I) & $\begin{array}{c}\text { Normal control A } \\
\text { (3 mL distilled water) }\end{array}$ & $\begin{array}{r}20.65 \\
\pm 2.10^{\mathrm{a}} \\
\end{array}$ & $\begin{array}{r}32.80 \\
\pm 3.90^{\mathrm{a}} \\
\end{array}$ & $\begin{array}{r}4.2 \\
+0.35^{a} \\
\end{array}$ & $\begin{array}{r}9.54 \\
\pm 1.4^{\mathrm{a}} \\
\end{array}$ \\
\hline (II) & $\begin{array}{l}\text { DSS positive control } \\
2.5 \%(\mathrm{w} / \mathrm{v}) \text { in drinking } \\
\text { water }\end{array}$ & $\begin{array}{r}56.70 \\
\pm 6.54^{\mathrm{b}}\end{array}$ & $\begin{array}{r}13.76 \\
\pm 1.77^{\mathrm{b}}\end{array}$ & $\begin{aligned} & 1.3 \\
\pm & 0.16^{\mathrm{b}}\end{aligned}$ & $\begin{array}{r}3.25 \\
\pm 0.5^{\mathrm{b}}\end{array}$ \\
\hline (III) & $\begin{array}{c}\text { Normal control B } \\
\begin{array}{c}1 \text { mL of tween } 80,1 \% \\
\text { distilled water })\end{array}\end{array}$ & $\begin{array}{r}19.07 \\
\pm 3.25^{\mathrm{a}}\end{array}$ & $\begin{array}{r}35.44 \\
\pm 2.66^{\mathrm{a}}\end{array}$ & $\begin{array}{r}4.00 \\
\pm 0.28^{a}\end{array}$ & $\begin{array}{r}9.22 \\
\pm 1.1^{\mathrm{a}}\end{array}$ \\
\hline (IV) & $\begin{array}{c}\text { RENE } \\
(39.75 \mathrm{mg} / \mathrm{kg} \text { b.w. }) \\
\end{array}$ & $\begin{array}{r}19,50 \\
\pm 2.6^{\mathrm{a}} \\
\end{array}$ & $\begin{array}{r}34.05 \\
\pm 4.20^{\mathrm{a}} \\
\end{array}$ & $\begin{array}{r}4.1 \\
\pm 0.37^{a} \\
\end{array}$ & $\begin{array}{r}9.03 \\
\pm 1.3^{\mathrm{a}} \\
\end{array}$ \\
\hline (V) & $\begin{array}{c}\text { RENE }(39.75 \mathrm{mg} / \mathrm{kg} \\
\text { b.w.) + DSS }(2.5 \%(\mathrm{w} / \mathrm{v}) \\
\text { in drinking water) }\end{array}$ & $\begin{array}{r}24.30 \\
\pm 3.45^{\mathrm{c}} \\
\end{array}$ & $\begin{array}{r}33.9 \\
\pm 4.12^{\mathrm{a}}\end{array}$ & $\begin{array}{r}3.95 \\
\pm 14.0^{\mathrm{ac}}\end{array}$ & $\begin{array}{r}8.80 \\
\pm 12.1^{\mathrm{a}} \\
\end{array}$ \\
\hline
\end{tabular}

Table 4: Effect of the RENE (39.75 mg/kg b.w.) on thiobarbituric acid reactive substances (TBARS), reduced Glutathione (GSH) superoxide dismutase (SOD) and catalase (CAT) of DSS treated rats. Data shown are mean \pm standard deviation of number of 6 observations within each group. Data followed by the same letter are not significantly different at

$$
\mathrm{P} \leq 0.05 \text {. }
$$

Figures 5 and 6 displayed that DSS (2.5\%) promoted the TGFB1 and IL-4 protein expression in DSS- treated the group of rats compared with control group. Administration of RENE (39.75 mg/kg.b.w), led to a statistically significant decrease of TGFB1 and IL-4 protein expression relative to DSS treated group of rats after 21 days $(p<0.05)$. Agarose gel electrophoresis images of TGFB1, IL-4 and $\beta$-actin by RT-PCR support the present results figure 8 .

The Reverse Transcription-Polymerase Chain Reaction (RT-PCR) results (Figure 7) showed that significant decrease in the expression levels of colonic trefoil factor 3 (TFF3) in group of treated rats with DSS (2.5\%) when compared with normal control group of rats. Also, Administra-

\begin{tabular}{|c|c|c|c|c|c|}
\hline No. & Groups & $\begin{array}{l}\text { TNF- } \alpha \\
\text { (ng/ mg } \\
\text { protein) }\end{array}$ & $\begin{array}{c}\text { No } \\
(\text { nmol/mg } \\
\text { protein) }\end{array}$ & $\begin{array}{l}\text { cAMP } \\
\text { (pmol/ } \\
\text { mg pro- } \\
\text { tien) }\end{array}$ & \begin{tabular}{|c|} 
MPO \\
$(\mu \mathrm{mol} /$ \\
min/mg \\
protien $)$
\end{tabular} \\
\hline (I) & $\begin{array}{c}\text { Normal control A } \\
\text { (3 mL distilled water) }\end{array}$ & $\begin{array}{r}55.4 \\
\pm 4.76^{\mathrm{a}} \\
\end{array}$ & $\begin{array}{r}53.74 \\
\pm 4.29^{a} \\
\end{array}$ & $\begin{array}{r}27.5 \\
\pm 2.66^{\mathrm{a}} \\
\end{array}$ & $\begin{array}{r}0.15 \\
\pm 0.03^{a} \\
\end{array}$ \\
\hline (II) & $\begin{array}{l}\text { DSS positive control } \\
2.5 \%(\mathrm{w} / \mathrm{v}) \text { in } \\
\text { drinking water } \\
\end{array}$ & $\begin{array}{l}137.26 \\
\pm 8.70^{\mathrm{b}}\end{array}$ & $\begin{array}{r}86.00 \\
\pm 4.63^{b}\end{array}$ & $\begin{array}{r}15.43 \\
\pm 1.73^{b}\end{array}$ & $\begin{array}{r}0.36 \\
\pm 0.04^{\mathrm{b}} \\
\end{array}$ \\
\hline (III) & $\begin{array}{c}\text { Normal control B } \\
\text { (1 mL of tween } 80,1 \% \\
\text { distilled water })\end{array}$ & $\begin{array}{r}54.65 \\
\pm 3.25^{\mathrm{a}}\end{array}$ & $\begin{array}{r}54.17 \\
\pm 4.06^{\mathrm{a}} \\
\end{array}$ & $\begin{array}{r}27.00 \\
\pm 3.10^{a}\end{array}$ & $\begin{array}{r}0.16 \\
\pm 0.02^{\mathrm{a}} \\
\end{array}$ \\
\hline (IV) & $\begin{array}{c}\text { RENE } \\
\text { (39.75 mg/kg b.w.) }\end{array}$ & $\begin{array}{r}51.83 \\
\pm 2.6^{\mathrm{a}} \\
\end{array}$ & $\begin{array}{r}55.37 \\
\pm 4.64^{\mathrm{a}} \\
\end{array}$ & $\begin{array}{r}29.80 \\
\pm 2.65^{\mathrm{a}} \\
\end{array}$ & $\begin{array}{r}0.14 \\
\pm 0.02^{\mathrm{a}} \\
\end{array}$ \\
\hline (V) & $\begin{array}{c}\text { RENE (39.75 mg/ } \\
\text { kg b.w.) + DSS }(2.5 \% \\
\text { (w/v) in drinking } \\
\text { water) }\end{array}$ & $\begin{array}{r}58.50 \\
\pm 6.44^{\mathrm{a}}\end{array}$ & $\begin{array}{r}62.11 \\
\pm 3.95^{\mathrm{c}}\end{array}$ & $\begin{array}{r}25.20 \\
\pm 2.55^{\mathrm{ac}}\end{array}$ & $\begin{array}{r}0.19 \\
\pm 0.01^{\mathrm{a}}\end{array}$ \\
\hline
\end{tabular}

Table 5: Effect of the RENE (39.75 mg/kg b.w.) tumor necrosis factor alpha (TNF- $\alpha$ ), nitric oxide (NO), cyclic adenosine monophosphate (cAMP) and myeloperoxidase (MPO) of DSS treated rats.

Data shown are mean \pm standard deviation of number of 6 observations within each group. Data followed by the same letter are not significantly different at $\mathrm{P} \leq 0.05$.

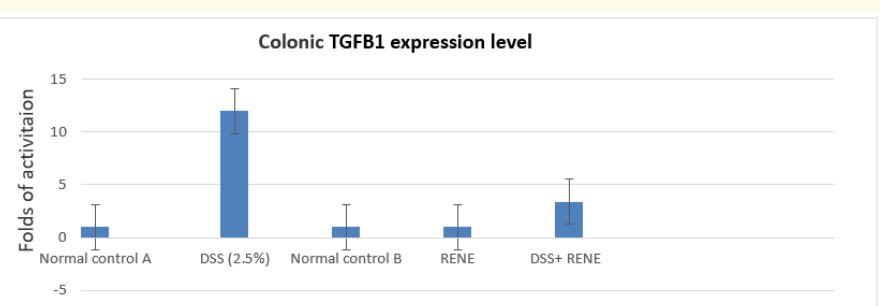

Figure 5: Effects of RENE on gene expression and extracellular level of colonic transforming growth factor beta 1 (TGFB1) of DSS treated rats.

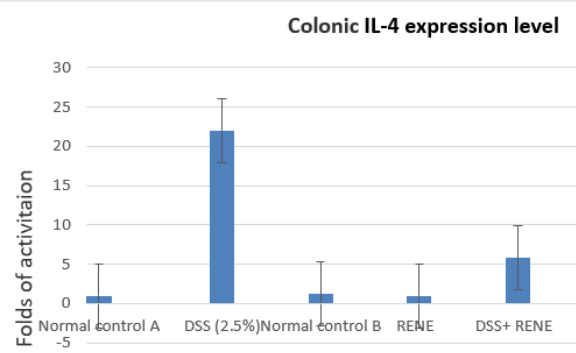

Figure 6: Effects of RENE on gene expression and extracellular level of colonic interleukin-4 (IL-4) of DSS treated rats. 


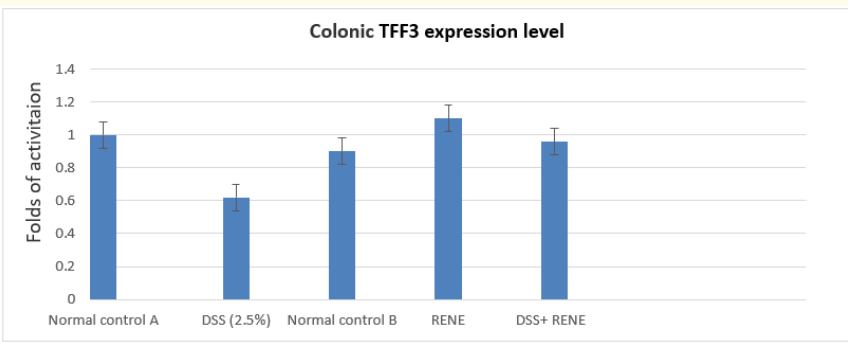

Figure 7: Effects of RENE on gene expression and extracellular level of colonic trefoil factor 3 (TFF3) of DSS treated rats.

tion of RENE (39.75 mg/kg.b.w), led to a statistically significant decrease of TFF3 protein expression relative to DSS treated rats ( $\mathrm{p}$ $<0.05$ ). Agarose gel electrophoresis images of TFF3 and $\beta$-actin by RT-PCR support the present results figure 8.

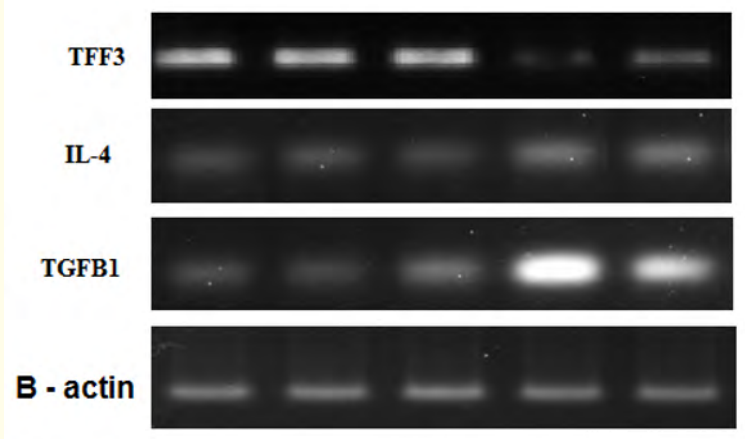

Figure 8: Agarose gel electrophoresis images of colonic TGFB1, IL-4, TFF3 and $\beta$-actin of DSS treated rats.

Histopathological examination in figure 9 (1-5) showed that Groups 1, 3 and 4 demonstrated normal morphological structures of intestinal wall with apparent intact intestinal crypts and lining epithelium (arrow), intact submucosa (star) as well as outer muscular coat with intact vasculatures.

Group 2 (DSS 2.5\% positive control) showed focal areas of necrosis in lining mucosa with disorganized glandular elements (arrow) accompanied with moderate mucosal and submucosal inflammatory cells infiltrates, edema (black star) as well as congested submucosal blood vessels (red star). Group 5 showed well organized intestinal glandular elements (arrow) with minimal records of abnormal alterations with minimal submucosal inflammatory cells records or edema (star).

\section{Discussion}

Ulcerative colitis is considered to be a TH2 and Crohn's a TH1 mediated inflammatory disease, although this assertion is los- ing favour as discussed previously [46]. However in experimental models it is still an important assumption that those models in which the cytokine milieu is balanced in favour $\mathrm{T}_{\mathrm{H}} 2$ (IL-4, IL-5 and IL-13) are mimicking UC and those in which the cytokine milieu is balanced in favour $\mathrm{T}_{\mathrm{H}} 1$ (INF- $\gamma$, IL-2 and TNF- $\alpha$ ) [47]. Despite the potential pitfalls of these assumptions, murine models offer a useful method of measuring miRNA and inflammatory cytokine levels under conditions which can be mapped into human disease and inflammatory processes.

In this study, we explain the co-relation between the TGFB1 gene expression and $\left(\mathrm{T}_{\mathrm{H}} 2\right) \mathrm{IL}-4,\left(\mathrm{~T}_{\mathrm{H}} 1\right) \mathrm{TNF}-\alpha$ and trefoil factor 3 (TFF3) inflammatory mediators.

TGFB1 gene signaling pathway is known to play a multifunctional role in inflammatory response to sterile and infectious threat and targeting TGFB1 is currently considered a very interesting novel strategy for the treatment of inflammatory diseases [48].

The present results proved the in vitro inhibitory activity of RENE against LPS-induced TGFB1 gene expression in human intestinal colorectal adenocarcinoma cell line and human colon carcinoma cell line HT29. In the present study, cell lines treated with LPS and cultured for 24 hours. Results showed that RENE significantly decreases the release of the extracellular TGFB1 starting at 24 hours in the two cell lines.

Many studies have revealed the potential therapeutic effect of resveratrol against invasion and metastasis of colorectal cancer cells $[49,50]$. In that study, we suggested that RENE inhibited expression of TGF $\beta 1$ and metastasis through MALAT1 mediated $\beta$-catenin signaling pathway. Here, we observed a previously unknown mechanism, in which RENE could inhibit invasion and migration via reversing epithelial-to-mesenchymal transition induced by TGF $\beta 1$.

The degree of inflammatory activity in all models of experimental colitis was measured in 3 ways; the first is by determining the weight change of each rat daily throughout each experiment. The second is by measuring the length of resected colon and the third is by visual analysis of the resected colon [51].

Measuring daily weights serves two purposes; the first is to measure wasting as a pseudo-marker of inflammatory activity and thus use the measured weight to predict when the inflammation is maximal and the best time to harvest tissue [52]. The second purpose is to monitor the welfare of the rats. Although weight loss alone is a poor predictor of wellbeing [48] it is still accepted that weight loss $>20 \%$ is a criteria for euthanasia and an indication that the experimental design may be too aggressive. 
Additional indicators of the degree of colonic inflammation is conducted by a visual inspection for thickening, strictures, dilations and quality of the stool followed by measurement of the weight of colon after harvesting and removal of stool [52]. Together the three measures of inflammatory activity ensured that the experiments were conducted at the optimal time following chemical induction $[48,49]$.

In our study, exposure to DSS (2.5\%) in drinking water for 7 days, induced acute colitis with an increased DAI score and colon weight/length ratio. Abdel-Maksoud., et al. [47] have reported a significant correlation between the DAI score and pathological changes in DSS induced acute and chronic colitis. DSS induced colitic animals exhibited a significant weight loss, developed bloody diarrhea and reduction in the length of the colon are considered as the cardinal signs of IBD [50].

RENE (39.75 mg/k.b.w.) tended to restore the rate of weight gain. The effects on weight gain correlated well with the changes in colon length and colon mass index. The DSS induced decrease in colon length may be related to the submucosal edema shown histologically while the colon shortening may be associated with its thickening due to edema and infiltration of inflammatory cells into the lamina propria and submucosa $[12,14]$. RENE led to marked reduction in the inflammatory infiltrate in both lamina propria and submucosa and dose-dependently protected against changes in colon length.

Hussein [22] showed that resveratrol, inhibits inflammatory cytokine release from alveolar macrophages isolated from patients with inflammation.

During DSS induced colitis, the antioxidant status of the colonic tissue was altered and resulted in the increased production of reactive oxygen species (ROS). According to a previous study on the antioxidant enzyme profile in a DSS induced model, a marked depletion of the cellular antioxidant GSH was observed [49]. Clinical studies on IBD also revealed the imbalance in antioxidant status [22]. The antioxidant profile was restored by RENE treatment, which suggested its anti-oxidant property [45].

Many studies have attempted to describe resveratrol's antioxidative effects in vivo, including one study that used a DSS-induced
UC mouse model [8-10]. These authors found that resveratrol ameliorated UC, decreased mucosal inflammation, and increased the activity of superoxide dismutase and glutathione peroxidase, demonstrating that resveratrol can modulate the expression of antioxidant enzymes. In these rats, myeloperoxidase activity and IL-8, TNF- $\alpha$ and interferon- $\gamma$ production were significantly reduced in a dose-dependent manner in response to resveratrol [13-15].

The overexpression of TGFB1 and IL-4 in the DSS group than in the control group. However, DSS-induced highly expressed proinflammatory cytokines were significantly regulated by RENE. Furthermore, pro-inflammatory cytokines (TNF- $\alpha$, NO and MPO) levels were also detected. IL-4 is produced by highly differentiated Th4 cells and is an effective mediator of inflammation (66).

Our results in confirmed with Hussein., et al. [51] who, reported oral administration of resveratrol can prevent the onset of DSSinduced mouse colitis by down-regulating the phosphorylation of extracellular signal-regulated kinase and STAT3, two key mediators of NF- $\mathrm{BB}$ signalling and inflammation. Interestingly, Hussein., et al. [52] who, discovered that administration of resveratrol was able to regulate MPO in a DSS rat model.

Treatment with RENE showed overall protective effects in the intestine, resulting in improved DAI like that for normal control group of rats. However, it may act through other pathways rather than just regulating goblet cell proliferation and its associated TFF3 expression.

Trefoil factor (TFF)-3 is a tissue repair factor involved in the regulation of epithelial restitution and epithelial cell migration [39].

These results confirms those previously obtained in the stools of IBD patients, where the presence of the protein directly correlated to the grade of mucosal inflammation and therefore it was proposed as a valuable novel biomarker of intestinal inflammation [46]. Moreover, we show, in the present study, that TGFB1 is strongly decreased by RENE treatment, still supporting the role of the latter as a downregulator of inflammation.

Histological examination of colonic sections revealed an altered architecture of colon mucosa with typical inflammatory changes in colonic architecture such as crypt and surface epithelial loss as 
well as infiltration of inflammatory cells and complete destruction of the epithelial architecture. The severity of the disease increases with chronicity. These macroscopic and microscopic alterations observed in our study were in agreement with numerous studies reported on DSS induced UC models in rats [46]. RENE led to marked reduction in the inflammatory infiltrate in both lamina propria and submucosa and dose-dependently protected against changes in colon length and mass index.

\section{Conclusions}

Present data evidence that secreted TGFB1 is a proinflammatory cytokine and an active protagonist of gut mucosal inflammation. Several methods have been proposed for inhibiting TGFB1 secretion and ensuing inflammation. In this study, we explored in vitro and in vivo the potential of RENE, a TGFB1 inhibitor, as an antiinflammatory compound and showed that it strongly ameliorates DSS-induced colitis in rats. We reason that RENE may represent an innovative tool for the management of human intestinal inflammation.

\section{Declarations}

Ethics Approval and Consent to Participate

Ethical approval for the data collection was granted by the Research Ethics Committee at the Faculty of Applied Medical Sciences, October 6 University, Egypt (No. 20191118). No humans were used studies that are base of this research, in-vitro experiments and in vivo lab. animals only were used.

\section{Consent for Publication}

The authors gave consent for their data to be used in the article

\section{Availability of Data and Materials}

Supporting data will be made available as it contains biochemical and molecular data to prove the structure of obtained nanoparticles as well as their anti-inflammatory properties in the DSS model of colitis in rats.

\section{Competing Interests}

The authors declare no conflict of interest, financial or otherwise.

\section{Funding}

The authors are not currently in receipt of any research funding.

\section{Authors' Contributions}

Experimental design of the present study was carried out by all authors. Preparation of resveratrol nanoemulsion and its characterization was carried out by Riham A. Mahmoud, Omnia H. Bastawesi and Mohamed S. Naser eldin. Treatment of lab. animals with resveratrol nanoemulsion was carried out Riham A. by Mahmoud, Omnia H. Bastawesi. Biochemical and molecular investigation was carried out by Ali A. Ali Mohammed A. Hussein. Wrote the protocol, wrote the first draft of the manuscript, managed the analyses of the study, managed the literature searches was carried out in collaboration between all authors. All authors read and approved the final manuscript.

\section{Bibliography}

1. Ghosh S and Mitchell R. "Impact of Inflammatory Bowel Disease on quality of life: Results of the European Federation of Crohn's and Ulcerative Colitis Associations (EFCCA) patient survey". Journal of Crohn's and Colitis 1.1 (2007): 10-20.

2. Creighton CJ., et al. "Molecular profiling uncovers a p53-associated role for microRNA-31 in inhibiting the proliferation of serous ovarian carcinomas and other cancers". Cancer Research 70.5 (2010): 1906-1915.

3. Danese S. "New therapies for inflammatory bowel disease: from the bench to the bedside". GUT 61.6 (2012): 918-932.

4. Solbers I., et al. "Clinical course in Crohn's disease: results of a Norwegian population-based ten-year follow-up study". Clinical Gastroenterology and Hepatology 5.12 (2007): 1430-1438.

5. Evans P and Pardi DS. "Extraintestinal manifestations of inflammatory bowel disease: focus on the musculoskeletal, dermatologic, and ocular manifestations". MedGenMed Gastroenterology 9.1 (2007): 55.

6. Chong MM., et al. "The RNAseIII enzyme Drosha is critical in T cells for preventing lethal inflammatory disease". Journal of Experimental Medicine 205.9 (2007): 2005-2017. 
7. Cobb BS., et al. "A role for Dicer in immune regulation". Journal of Experimental Medicine 203.11 (2006): 2519-2527.

8. Ceppi M., et al. "MicroRNA-155 modulates the interleukin-1 signaling pathway in activated human monocyte-derived dendritic cells". Proceedings of the National Academy of Sciences of the United States of America 106.8 (2009): 2735-2740.

9. Allocca M., et al. "can il-23 be a good target for ulcerative colitis?" Best Practice and Research: Clinical Gastroenterology 3233 (2018): 95-102.

10. Jeoung Br., et al. "Ganghwaljetongyeum, an anti-arthritic remedy, attenuates synoviocyte proliferation and reduces the production of proinflmmatory mediators in macrophages: The therapeutic effect of GHJTY on rheumatoid arthritis". BMC Complementary Medicine and Therapies 13 (2013): 47.

11. Jeong HY., et al. "Anti-inflmmatory activity of citric acid-treated wheat germ extract in lipopolysaccharide-stimulated macrophages". Nutrients 9 (2017).

12. Xiang Y., et al. "Brusatol inhibits growth and induces apoptosis in pancreatic cancer cells via JnK/p38 MaPK/nF-kb/ Stat3/Bcl-2 signaling pathway". Biochemical and Biophysical Research Communications 487 (2017): 820-826-13.

13. Xie Z., et al. "Hepatitis c virus nonstructural 5 a protein $(\mathrm{HcV}$ $\mathrm{nS5a}$ ) inhibits hepatocyte apoptosis through the nF-kb/mir503/bcl-2 pathway". Molecular Cells 40 (2017): 202-210.

14. Eissa N., et al. "chromofungin (cHr: cHGa47-66) is downregulated in persons with active ulcerative colitis and suppresses pro-inflmmatory macrophage function through the inhibition of nF- $\kappa$ B signaling". Biochemical Pharmacology 145 (2017): 102-113.

15. Fuschiotti P. "Role of IL-13 in systemic sclerosis". Cytokine 56 (2011): 544-549.

16. Mifflin RC., et al. "Intestinal myofibroblasts: targets for stem cell therapy". American Journal of Physiology-Gastrointestinal and Liver Physiology 300 (2011): G684-G696.

17. Speca S., et al. "Cellular and molecular mechanisms of intestinal fibrosis". World Journal of Gastroenterology 18 (2012): 3635-3661.
18. Roberts A B., et al. "Smad3: a key player in pathogenetic mechanisms dependent on TGF-beta". Annals of the New York Academy of Sciences 995 (2003): 1-10.

19. Okayasu I., et al. "A novel method in the induction of reliable experimental acute and chronic ulcerative colitis in mice". Gastroenterology 98 (1990): 694-702.

20. Guerrero RF., et al. "Wine, resveratrol and health: A review". Natural Product Communications 4 (2009): 635-658.

21. Baur JA., et al. "Therapeutic potential of resveratrol: The in vivo evidence". Nature Reviews Drug Discovery 5 (2006): 493-506.

22. Hussien MA. "Prophylactic effect of resveratrol against Ethinylestradiol-Induced Liver Cholestasis". Journal of Medicinal Food 16.3 (2013): 246-254.

23. Zhi Z., et al. "Polyphenols from Camellia sinenesis attenuate experimental cholestasis-induced liver fibrosis in rats". American Journal of Physiology-Gastrointestinal and Liver Physiology 285 (2003): G1004-G1013.

24. Guerrero RF., et al. "Wine, resveratrol and health: A review". Natural Product Communications 4 (2009): 635-658.

25. Baur JA and Sinclair DA. "Therapeutic potential of resveratrol: The in vivo evidence". Nature Reviews Drug Discovery 5 (2006): 493-506.

26. Hussein MA. "A convenient mechanism for the free radical scavenging activity of resveratrol". International Journal of Phytomedicine 3 (2011): 459-469.

27. Majid M., et al. "Comparison of effect of resveratrol and vanadium on diabetes related dyslipidemia and hyperglycemia in streptozotocin induced diabetic rats". Advanced Pharmaceutical Bulletin 2 (2011): 81-86.

28. Kreuter J. "Nanoparticles-a historical perspective". International Journal of Phytomedicine 331 (2007): 1-10.

29. De Jong WH and Borm PJ. "Drug delivery and nanoparticles: applications and hazards". International Journal of Nanomedicine 3 (2008): 133-149. 
30. Cho K., et al. "Therapeutic nanoparticles for drug delivery in cancer". Clinical Cancer Research 14 (2008): 1310-1316.

31. Ibrahim WM., et al. "Novel sulpiride-loaded solid lipid nanoparticles with enhanced intestinal permeability". International Journal of Nanomedicine 9 (2014): 129-144.

32. Martín AR., et al. "The effects of resveratrol, a phytoalexin derived from red wines, on chronic inflammation induced in an experimentally induced colitis model". British Journal of Pharmacology 147 (2006): 873-885.

33. Cianciulli A., et al. "Modulation of NF- $\kappa$ B activation by resveratrol in LPS treated human intestinal cells results in downregulation of PGE2 production and COX-2 expression". Toxicology In Vitro 26 (2012): 1122-1128.

34. Hussein MA., et al. "Resveratrol nanoemulsion; a promising protector against Ethinylestradiol-induced Hepatic Cholestasis in Female Rats". Journal of Biomolecular Research and Therapeutics 8 (2019): 175-183.

35. Maxwell JR., et al. "Methods of Inducing Inflammatory Bowel Disease in Mice". Current Protocols in Pharmacology Chapter 5 (2009): Unit 5.58.

36. Nagib MM., et al. "Anti-inflammatory and anti-oxidant activities of olmesartan medoxomil ameliorate experimental colitis in rat". Toxicology and Applied Pharmacology 271 (2013): 106-113.

37. Okhawa H., et al. "Assay of lipid peroxides in animal tissues by thiobarbituric acid reaction". Analytical Biochemistry 95 (1979): 351

38. Sedlak J., et al. "Estimation of total protein bound and nonprotein sulfhydryl groups in tissue with Ellmans reagent". Analytical Biochemistry 25 (1968): 293-298.

39. Misra HP and Fridovich I. "The role of superoxide anion in the autooxidation of epinephrine anion in the autooxidation of epinephrine and a simple assay of superoxide dismutase". Journal of Biological Chemistry 247 (1972): 3170.

40. Tukahara., et al. "Hypocatalasemia, a new genetic carrier state”. Journal of Clinical Investigation 29 (1960): 610-616.
41. Kawakami M., et al. "Measurement of interleukin-6, interleukin-10, and tumor necrosis factor-alpha levels in tissues and plasma after thermal injury in mice". Surgery 121 (1997): 440.

42. Miranda KM., et al. "A rapid, simple spectrophotometric method for simultaneous detection of nitrate and nitrite". Nitric OXide 5 (2001) 62-71.

43. El-Ashmawy N., et al. "Roflumilast, type 4 phosphodiesterase inhibitor, attenuates inflammation in rats with ulcerative colitis via down-regulation of iNOS and elevation of Camp". International Immunopharmacology 56 (2018): 36-42.

44. Krawisz J., et al. "Quantitative assay for acute intestinal inflammation based on myeloperoxidase activity: Assessment of inflammation in rat and hamster models". Gastroenterology 87 (1984): $1344-1350$.

45. Lowry 0., et al. "Protein measurement with the folin phenol reagent". Journal of Biological Chemistry 19 (1951)3: 265-275.

46. Sanchez-Munoz, F., et al. "Role of cytokines in inflammatory bowel disease". World Journal of Gastroenterology 14 (2008): 4280-4288.

47. Abdel-Maksoud H., et al. "Cranberry extract as a functional food in treatment of myocardial toxicity induced by nicotine in Rats". International Journal of Pharma Sciences 5.4 (2015): 1174-1180.

48. Ali HA., et al. "Biochemical effect of cranberry extract on experimentally induced myocardial infarction". Benha Veterinary Medical Journal 32.1 (2017): 59-66.

49. Hassan SA., et al. "Protective Effect of Cranberry Extracts against Oxidative Stress and DNA Damage Induced by Diclofenac Sodium in Kidney of Male Albino Rate". Chinese Medicine 8 (2017): 113-131.

50. El-gizawy A., et al. "Chemical Composition of the Essential oil of the Leaves of Pimenta diocia (L.) Merr. and Pimenta racemosa (Mill.) cultivated in Egypt and evaluation of their in-vitro antioxidant and antidiabetic". International Journal of Phytomedicine 4 (2018): 226-234. 
51. Hussein MA. "Cardioprotective effects of astaxanthin against isoproterenol-induced cardiotoxicity in rats". Journal of Nutrition and Food Sciences 5 (2015): 1-6.

52. Hussein MA. "Purslane Extract Effects on Obesity-Induced Diabetic Rats Fed a High-Fat Diet". Malaysian Journal of Nutrition 3 (2010): 419-429.

\section{Assets from publication with us}

- Prompt Acknowledgement after receiving the article

- Thorough Double blinded peer review

- Rapid Publication

- Issue of Publication Certificate

- High visibility of your Published work

Website: www.actascientific.com/

Submit Article: www.actascientific.com/submission.php

Email us: editor@actascientific.com

Contact us: +919182824667 